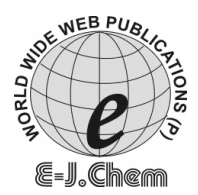

http://www.e-journals.net
ISSN: 0973-4945; CODEN ECJHAO

E-Journal of Chemistry

Vol. 5, No.4, pp. 736-741, October 2008

\title{
Anti-Nutritional Factors and Potassium Bromate Content in Bread and Flour Samples in Uyo Metropolis, Nigeria
}

\author{
A.S. EKOP, I.B. OBOT* and E. N. IKPATT \\ Department of Chemistry, Faculty of Science, \\ University of Uyo, Uyo, Nigeria. \\ proffoime@yahoo.com
}

Received 27 August 2007; Accepted 20 October 2007

\begin{abstract}
The aim of the study is to evaluate the anti-nutritional composition factors and potassium bromate content of some selected bread and flour samples in Uyo Metropolis. The result of the analysis shows that, though the concentration of phytic acid and tannins was high in both the bread and flour samples their concentrations did not exceed lethal doses. The potassium bromate content was minimal in all the bread and flour samples and within safe limits of residual bromide found in flour as specified by the US Food and Drug Administration. The concentrations of the anti-nutritional factors in the bread and flour samples were partially different from each other when subjected to the students $t$-test statistics.
\end{abstract}

Keywords: Anti-nutritional factors, Potassium bromate, Bread, Flour.

\section{Introduction}

Uyo is the capital of Akwa Ibom State in Southern Nigeria. Information available on the State's website (www.akwaibomstategov.com) shows that the state has a population of 2.5 million and an area of 8,412 square kilometer, has a latitude $4^{\circ} 32^{\prime}$ and $5^{\circ} 53^{\prime}$ North and longitude $7^{\circ} 25^{\prime}$ and $8^{\circ} 25$ East.

In recent times, from personal experience and literature report, it has been observed that bread has gradually become a major food item in the menu of the residents of Uyo metropolis. Therefore there is a great need to ascertain the anti-nutritional factors and potassium bromate content of bread and flour samples.

Anti-nutrients are chemical substances in food that do not offer nourishment to the body. e.g. phytic acid, oxalates, tannins and hydrocyanic acid. The effect of these antinutrients in the body depends on the type and the concentration in which it is present in the food material ${ }^{1-3}$. 
Phytic acid lowers the utilization of elements like calcium, magnesium, zinc and iron due to its ability to form insoluble salts with their ions ${ }^{4}$.McCance and Widdowson ${ }^{1}$ determined the phytic acid content of 64 foodstuffs and found that $20-60 \%$ of the phytate in cereals are excreted by human beings unchanged in the faeces. It has also been reported by Bushway et al., ${ }^{2}$ that the maximum tolerable dose of phytate in the body is from 250 to $500 \mathrm{mg} / 100 \mathrm{~g}$.

Oxalate is produced and accumulated in many crop plants and pasture weeds ${ }^{5}$. When taken into the body, oxalates do not only combine with calcium but also with magnesium to form insoluble salts which are not available to the body.

Cyanides are a group of O-glycosides formed from decarboxylated amino acids. Cyanides can inhibit cellular oxidation by combining with the catalytic ion of cytochrome oxidase leading to elimination of the active unit concerned with transfer of electrons to molecular oxygen ${ }^{15}$. Hydrocyanic acid has also been found to inhibit the activity of vitamin $\mathrm{K}$ dependent carboxylase of the liver ${ }^{4}$. In addition, Aremu ${ }^{5}$ estimated that the per capita daily intake of hydrocyanate in Nigeria was $8 \mathrm{mg}$, almost $90 \%$ of which is from garri alone.

Tannins are polyhydric phenols. The two distinctive groups are the hydrolysable tannins (so called because they may be readily hydrolyzed into a mixture of carbohydrates and phenols) and condensed tannins, which are complex flavonoid polymers ${ }^{6}$. Tannins form insoluble complexes with proteins, carbohydrates and lipids leading to a reduction in digestibility of these nutrients ${ }^{7,8}$. Other nutritional effects that have been attributed to tannins include damage to the intestinal tract, toxicity of tannins absorbed from the gut, interference with the absorption of iron and a possible carcinogenic effect.

Potasssium bromate is a flour improver that acts as a maturing agent. It acts principally in the late dough stage giving strength to the dough during late proofing and early baking. In the early 1990's the World Health Organization (WHO) discovered that potassium bromate if added to dough which subsequently is produced as bread has the capacity to cause such diseases as cancer, kidney failure and several other related diseases. The use of bromates has been banned in numerous countries. In Nigeria, the potassium bromate use in bread making was banned in 1993 .

The present study is aimed at analyzing and determining the anti-nutritional factors and potassium bromate contents in some selected bread and flour samples in Uyo metropolis.

\section{Experimental}

Samples of bread and flour were purchased from sellers within Uyo metropolis. The alkaline titration method recommended by A.O.A.C ${ }^{9}$ was adopted for the determination of the hydrocyanic acid content while the tannin content was determined using the Vanillin-HCl reagent method of Burns ${ }^{10}$. The oxalate content of the samples was determined using the potassium permanganate titration method of $D y e^{11}$, while the phytic acid content was determined using the method of McCance and Widdowson ${ }^{1}$. The potassium bromate content of the samples was determined using the titration method as recommended by A.O.A.C ${ }^{9}$.

\section{Results and Discussion}

The results of the anti-nutritional and potassium bromate contents of some bread and flour samples in Uyo were as shown in Tables 1 and 2. Table 1 shows the composition of the antinutritional substances determined. These included hydrocyanic acid, oxalate, phytate and tannins. The anti-nutritional roles of toxicants have been reported ${ }^{2,3}$, and they include inhibitory role such as inhibition of the activity of vitamin $\mathrm{K}$ dependent carboxylase of the 
liver, etc. The hydrocyanic acid content in the analyzed bread and flour samples respectively were in the range 4.32 to $6.48 \mathrm{mg} / 100 \mathrm{~g}$ and 4.32 to $10.80 \mathrm{mg} / 100 \mathrm{~g}$. The result shows a low hydrocyanic acid content. Chakraborty and Eka ${ }^{12}$ reported the hydrocyanic acid content of Wheat Triticum spp to be $81.36 \mathrm{mg}$. However, Edet ${ }^{13}$ reported that there was no hydrocyanic acid observed in his studies on some bread samples. There was a significant difference $(\mathrm{P} \leq 0.05)$ in the level of hydrocyanic acid content in bread and flour. This is expected because the release of HCN from the precursor glycosides is enzymatic. Heat treatment thus affects the activity of this enzyme ${ }^{14}$.

$\mathrm{HCN}$ is a very volatile compound, which can easily be eliminated by heat. Cyanide can inhibit cellular oxidation by combining with catalytic ion of cytochrome oxidase leading to elimination of the active unit concerned with transfer of electrons to molecular oxygen ${ }^{15}$. Hydrocyanic acid has also been found to inhibit the activity of vitamin $\mathrm{K}$ dependent carboxylase of the liver ${ }^{4}$.

The lethal dose of hydrocyanic acid reported by Eneobong ${ }^{4}$ was $35 \mathrm{mg}$ per kg body weight. On the other hand, Burn ${ }^{10}$, reports that the body has a way of detoxifying small doses of cyanide in food by converting it to thiocyanide, which is excreted in the urine. However, traces of cyanide in food are of immense importance since it helps to convert inactive form (hydroxycobalamine) to the active form (cyanocobalamine). This research has shown that though the analyzed bread and flour samples contain $\mathrm{HCN}$, the HCN content is well below the lethal dose.

The level of oxalates in the bread samples was in the range 22.00 to $35.20 \mathrm{mg} / 100 \mathrm{~g}$ and 17.60 to $48.40 \mathrm{mg} / 100 \mathrm{~g}$ for the flour samples. These are slighter higher than the values obtained by Edet $^{13}$. Oxalates can form complexes with most essential trace elements therefore making them unavailable for enzymatic activities and other metabolic processes. Consumption of large doses of oxalic acid causes corrosive gastroenteritis, shock, convulsive symptoms, low plasma calcium, high plasma oxalates and renal damage ${ }^{4}$. The toxic range or lethal dose of oxalates has been reported ${ }^{14}$ to be between 3-5 $\mathrm{g}$ for man. This study therefore reveals a safe margin for the analyzed bread and flour samples. Edet ${ }^{13}$, however stated that there was no incidence of oxalic acid poisoning reported in Nigeria.

The levels of phytate in the bread samples in $\mathrm{mg} / 100 \mathrm{~g}$ was in the range 291.25 to 299.43 while that of the flour samples still in $\mathrm{mg} / 100 \mathrm{~g}$ was in the range 288.05 to $298.00 \mathrm{mg} / 100 \mathrm{~g}$. There was a partial significant difference in the phytate of the bread and flour samples. Phytates are high in cereals and widely distributed in vegetables ${ }^{5}$. Phytic acid has complicated effect in the human system including indigestion of food and flatulence. Phytic acid inhibits the absorption and utilization of some mineral elements. Warnick ${ }^{15}$, observed that foods with greater than $19 \mathrm{mg}$ $/ 100 \mathrm{~g}$ phytic acid composition showed low iron diffusibility. Chakraborty and $\mathrm{Eka}^{12}$ reported the phytic acid content of wheat triticum spp to be $114.49 \mathrm{mg} \%$ while $\mathrm{Edet}^{13}$ studies on bread showed the phytic acid content to be in the range $74.70 \pm 0.10$ to $87.76 \pm 0.10 \mathrm{mg} / 100 \mathrm{~g}$. Although there are no available literature reports on the lethal dose of phytic acid, Chakraborty and Eka ${ }^{12}$ has reported that phytic acid is lost during processing.

Table 1 shows that the tannin content for bread was in the range 123.26 to $126.22 \mathrm{mg} / 100 \mathrm{~g}$ while that for flour was in the range 121.48 to $125.63 \mathrm{mg} / 100 \mathrm{~g}$. Tannins are polyhydric phenols and their role in the inhibition of trypsin, chymotrypsin, amylase and lipase activities have been confirmed $^{16}$. Tannins form insoluble complexes with proteins, carbohydrates and lipids leading to a reduction in digestibility of these nutrients ${ }^{3}$. Tannins are present in virtually all parts of plants and they have molecular weight ranging from 500-3000. When they coagulate digestive enzymes, these enzymes will not be available for their catalytic hydrolysis and this will affect the digestion of foods in the digestive tract ${ }^{14}$. This result also agrees with that of $\operatorname{Edet}^{13}$ with tannin content values of bread in the range $111.91 \pm 0.00$ to $129.82 \pm 0.10 \mathrm{mg} / 100 \mathrm{~g}$. 
Table 1. Anti-nutrients composition of some bread and flour samples in Uyo

\begin{tabular}{ccccccccc}
\hline $\begin{array}{c}\text { Parameters } \\
\mathrm{mg} / 100 \mathrm{~g}\end{array}$ & $\mathrm{~A}$ & $\mathrm{~B}$ & $\mathrm{C}$ & $\mathrm{D}$ & $\mathrm{E}$ & $\mathrm{F}$ & $\mathrm{G}$ & $\mathrm{H}$ \\
\hline Tannins & $126.22 \pm 0.20$ & $123.26 \pm 0.15$ & $125.04 \pm 0.01$ & $124.44 \pm 0.01$ & $125.63 \pm 0.20$ & $123.26 \pm 0.20$ & $125.63 \pm 0.30$ & $121.48 \pm 0.01$ \\
HCN & $6.48 \pm 0.02$ & $4.32 \pm 0.01$ & $6.48 \pm 0.10$ & $4.32 \pm 0.03$ & $8.64 \pm 0.50$ & $4.32 \pm 0.18$ & $10.80 \pm 0.30$ & $6.48 \pm 0.14$ \\
Phytates & $299.43 \pm 0.20$ & $295.16 \pm 0.15$ & $291.25 \pm 0.05$ & $296.58 \pm 0.01$ & $298.00 \pm 0.22$ & $288.05 \pm 0.10$ & $291.60 \pm 0.10$ & $297.29 \pm 0.15$ \\
Oxalates & $30.80 \pm 0.01$ & $35.20 \pm 0.20$ & $26.40 \pm 0.05$ & $22.00 \pm 0.30$ & $26.40 \pm 0.20$ & $26.40 \pm 0.10$ & $48.40 \pm 0.15$ & $17.60 \pm 0.10$ \\
\hline
\end{tabular}

* Mean of three determinations \pm standard deviation.

Table 2. Potassium bromate levels of some bread and flour samples in Uyo

\begin{tabular}{ccccccccc}
\hline & \multicolumn{4}{c}{ Bread Samples } & Flour Samples \\
\hline $\begin{array}{c}\text { Parameter } \\
\text { mg/100 g }\end{array}$ & A & B & C & D & E & F & G & H \\
$\begin{array}{c}\text { Potassium } \\
\text { Bromate }\end{array}$ & 0.108 & 0.378 & 0.270 & 0.135 & 0.216 & 0.108 & 0.108 & 0.054 \\
\hline
\end{tabular}


The potassium bromate levels for the bread samples A to D was respectively 0.108 $\mathrm{mg} / 100 \mathrm{~g}, 0.378 \mathrm{mg} / 100 \mathrm{~g}, 0.270 \mathrm{mg} / 100 \mathrm{~g}$ and $0.135 \mathrm{mg} / 100 \mathrm{~g}$. That of the flour samples was $0.216 \mathrm{mg} / 100 \mathrm{~g}, 0.108 \mathrm{mg} / 100 \mathrm{~g}, 0.108 \mathrm{mg} / 100 \mathrm{~g}$ and $0.054 \mathrm{mg} / 100 \mathrm{~g}$ respectively. Potassium bromate $\left(\mathrm{KBrO}_{3}\right)$ is an oxidizing agent that has been used as a food additive, mainly in the bread making process. This substance is also a mutagen and has shown the potential to cause cancer in laboratory animal studies ${ }^{17}$.

Although adverse effects are not evident in animal fed bread-based diets made from flour treated with potassium bromate, the substance is carcinogenic in rats and nephrotoxic in both man and experimental animals when given orally ${ }^{13}$. However, the potential seems to be weak in mice and hamsters. In contrast to its weak mutagenic activity in microbial assays, potassium bromate showed relatively strong potential in inducing chromosome aberrations both in vitro and in vivo. Active oxygen radicals generated from potassium bromate were implicated in its toxic and carcinogenic effects, especially because potassium bromate produced 8-hydroxydeoxyguanosine in the rat kidney ${ }^{1}$. It has been demonstrated that potassium bromate induces renal cell tumors, mesotheliomas of the peritoneum, and follicular cell tumors of the thyroid. In addition, experiments aimed at elucidating the mode of carcinogenic action have revealed that potassium bromate is a complete carcinogen, possessing both initiating and promoting activities for rat renal tumorigenesis.

Bromates are known to be formed when there is bromine dissolved in water ${ }^{17}$. They are undesirable products because of their carcinogenicity. Many foods have a natural content of bromine, as $\mathrm{Br}^{-}$, in the range $1-10 \mathrm{mg} / \mathrm{kg}$ and some foods considerably more; flour itself has natural bromine ${ }^{2,5}$ content of 2.4-7.7 mg/kg. The joint FAO/WHO committee on food additives has stated that the temporary acceptance level of potassium bromate in flour is $0-75 \mathrm{mg} / \mathrm{kg}$ providing that bakery products prepared from such treated flour contain negligible residues of potassium bromate. From the results, we see that the potassium bromate content of all the flour samples fall within this range.

The potassium bromate levels of the bread samples are also within this range. This signifies that the bread and flour samples are within safe limits of potassium bromate content. It can also be inferred that potassium bromate has not been added to the bread samples. Insufficient fact is known about the fate of bromate in other commodities other than baked flour products to establish an acceptable level of treatment. Information about bromate available on the website 'www.keymix.com', has normally that potassium bromate is used at levels less than 70 parts per million of flour or less than 45 parts per million of finished dough. It has also been opined that normal usage levels are 10 to 30 parts per million and when used at these low levels, a majority of the potassium bromate reacts. It goes ahead to aver that if there is any potassium bromate remaining; it evaporates during the baking process. The FDA however feels that 20 parts per billion or less of potassium bromate is safe.

\section{Conclusion}

The objective of this study was to analyze samples of bread and flour samples sold in Uyo metropolis to determine their anti-nutritional composition and potassium bromate content. The anti-nutritional content determined in $\mathrm{mg} / 100 \mathrm{~g}$ dry weight basis for tannins hydrocyanic acid, phytates and oxalates in bread and flour was within acceptable range. The potassium bromate levels in the bread samples in $\mathrm{mg} / 100 \mathrm{~g}$ was found to be $0.108,0.378,0.270$ and 0.135 and for the flour samples also in $\mathrm{mg} / 100 \mathrm{~g}, 0.216,0.108,0.108$ and 0.054 . The levels of hydrocyanic acid and oxalate in the bread and flour samples were well below the lethal dose. As expected in cereals, the phytic acid levels in the bread and flour samples were quite 
high. The tannin content was also high. The concentrations of phytic acid and tannins in the bread and flour were however not alarming when compared with their concentrations in other food stuffs as reported by Chakraborty and Eka (1978). The potassium bromate content were all within the safe limits of residual bromide found in flour as specified by the US Food and Drug Administration from where NAFDAC also derives her specifications.

\section{References}

1. McCance R A and Widdowson E M, Biochem J, 1935, 29, 2694.

2. Bushway R J Bureau J L and Gann D F, J Food Sci., 1998, 48, 84-86.

3. Demetz M South B Hanker H and Vermerc C, J Agric Food Chem., 1982, 28, 533-536.

4. Eneobong H N, Eating Right (A Nutrition Guide). Zoometer Print Communications Ltd. Nigeria, 2001.

5. Aremu C Y, Nig J Nutri. Sci, 1989, 10, 79-84.

6. Moles S and Waterwan N P G, Phytochemistry, 1987, 25 (1), 99-102.

7. Duel F and Stutz C, Biochemistry of Fruits and their Products. Academic Press, London. 1958, 1, 18-86.

8. Fisher S M, Food Review, 1996, 19 (1), 27-29.

9. Association of Official Analytical Chemist, A. O. A. C., In Official Methods of Analysis, $14^{\text {th }}$ Edition, Washington D. C. 1984.

10. Burns R E, Methods for estimation of tannins in grains sorghum, J Agronomy, 1971, 163, 511-513

11. Dye W B, Weeds. 1956, 4, 508

12. Chakraborty E R and Eka O U, West African Journal of Biological and Applied Chemistry. 1978, 21, $43-52$.

13. Edet U E, Nutrient content of bread. B.Sc project, University of Uyo, Nigeria. 2005.

14. Warnick T M, Plant Foods Hum Nutr., 1993, 46, 116-121.

15. Demetz M South B Hanker H and Vermerc C, J Agric Food Chem., 1982, 28, 533-536.

16. Griffits A W and Mosely G, J Sci Food Agric, 1980, 31, 255-259.

17. Atkins D P, Potassium bromate in bread. Index to MAFF UK Food surveillance Information sheets, 1993. 


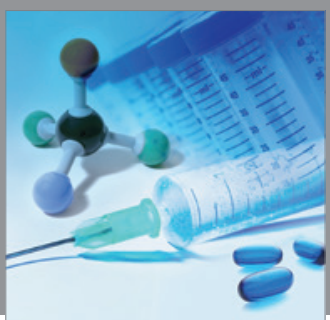

International Journal of

Medicinal Chemistry

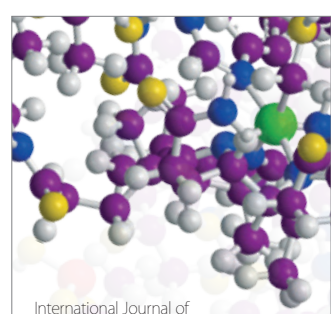

Carbohydrate Chemistry

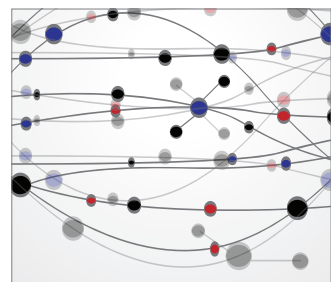

The Scientific World Journal
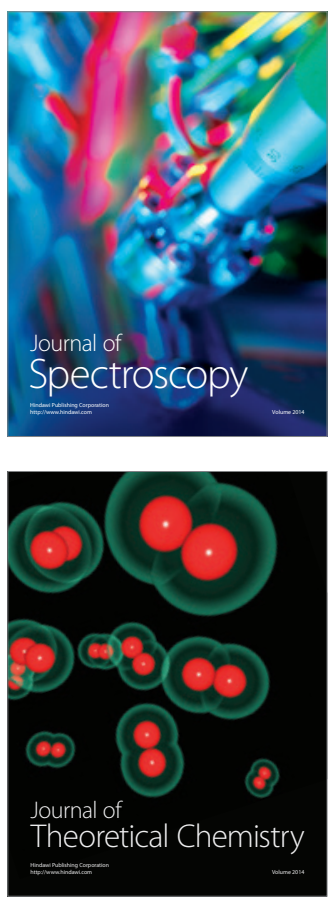
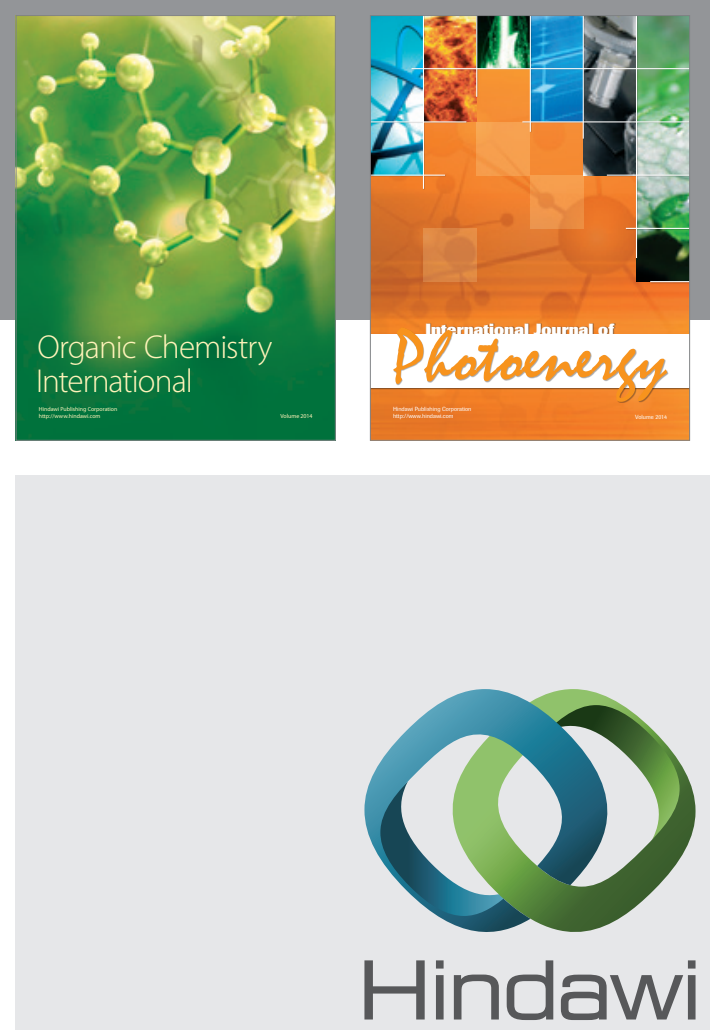

Submit your manuscripts at

http://www.hindawi.com
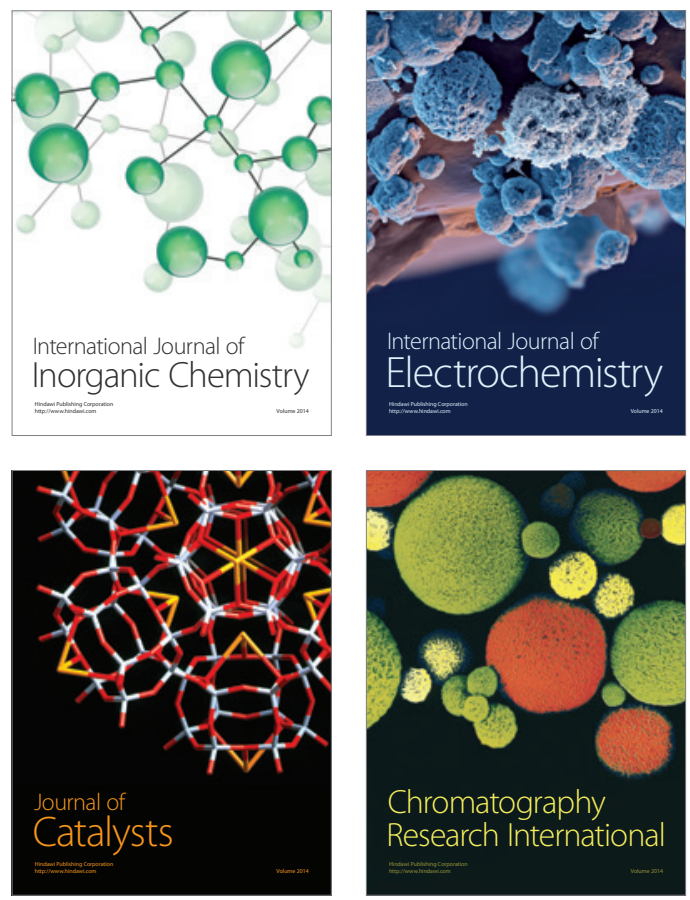
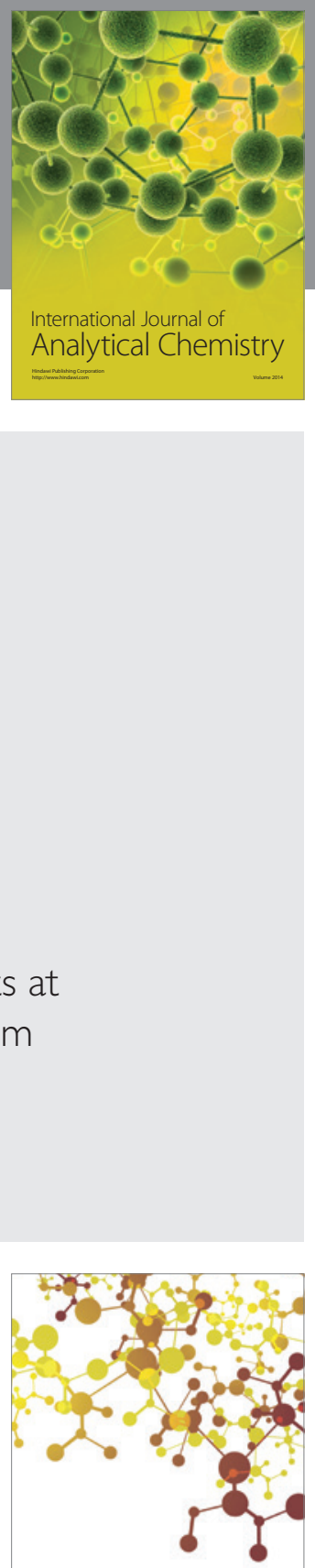

Journal of

Applied Chemistry
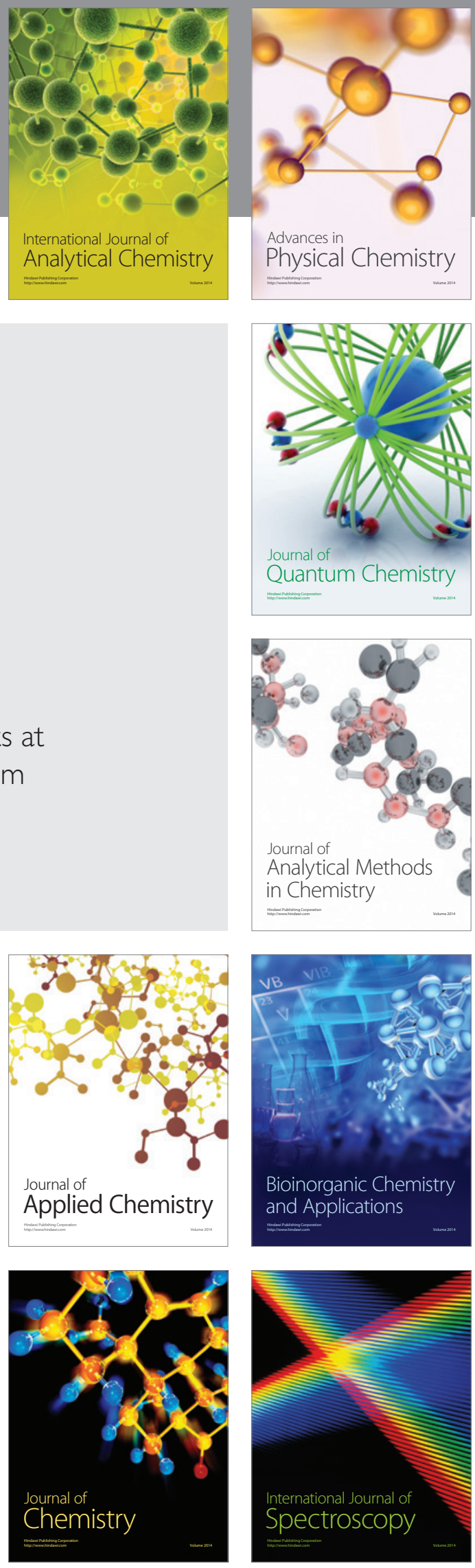